\title{
Stability of Vortex Structure on Core Switching
}

\author{
T. Sato, and Y. Nakatani \\ Graduate School for Informatics and Engineering, Univ. of Electro-Communications, 1-5-1 Chofugaoka, Chofu-shi, Tokyo, 182-8585, \\ Japan
}

The stability of the vortex structure on vortex core switching was investigated by using micromagnetic simulation. The method by the vortex core switching simulation by AC spin current is used to investigate this. Furthermore, the adequacy of the result was investigated by the evaluation of the magnetic energy. The switching simulation revealed that the vortex core did not switch around the transition dimension of magnetic disks between single-domain structure and the vortex structure in a remanent state, and the disk diameter needed to be increased to about 20 to $80 \mathrm{~nm}$ for stable vortex core switching compared with the stability limit in the remanent state. Furthermore, the results we obtained from our evaluation of magnetic energy agreed with the results obtained by simulating vortex core switching. Therefore, the result of the core switching simulation is also assured by the evaluation of magnetic energy.

Key words: micromagnetic simulation, magnetic vortex, stability of vortex structure

\section{磁気渦コア反転における磁気渦構造の安定性}

\author{
佐藤知徳・仲谷栄伸
}

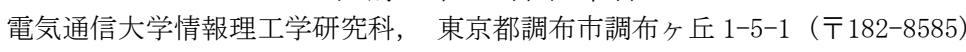

\section{1. はじめに}

現在，次世代不揮発性メモリのメモリセルとして，サブ ミクロンサイズの磁気ディスクに現れる磁気渦を用いる方

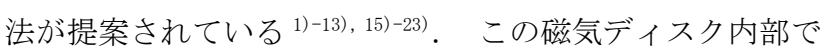
は, 静磁エネルギーを減少させるために渦状の磁化構造が 出現する.この渦構造には 2 つの特徵量がある. 1 つは渦 の回転方向(Chirality)であり，もう 1 つは渦の中心(渦コ ア)での磁気モーメントの向き(Polarity)である ${ }^{1)}$. 磁気渦 構造は外部磁界に対して非常に安定であるため, これらの 特徵を利用することで磁気メモリへの応用が可能であると 考えられていた。 しかしながら, 磁気渦構造が非常に安定 な構造であるために, 例えば DC 磁界で渦コアの向きを変 えるためには磁気ディスク面直方向に約 3000 Oe の非常に

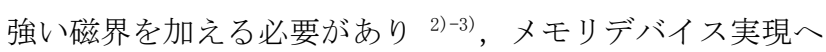
の問題となっていた。しかしながら近年，磁界やスピン電 流を用いて効率よく渦コアの向きを反転させる種々の手法 が提案され, 現在渦コアの操作に関する研究が盛んに行わ れている ${ }^{4)-11)}$.

メモリデバイスを実現するためのもう一つの問題とし て渦構造の安定性が挙げられる. メモリの集積度は磁気デ イスクサイズに依存するが, 渦構造がディスクに現れる条 件もまたディスクサイズに依存する ${ }^{12)}$.このため渦構造が 安定して現れるディスクサイズの調査が必要となる. 残留 磁化状態において磁気渦構造が安定に出現するディスクの サイズについては既に報告がされている ${ }^{12), 13)}$. しかしな がら, 渦コアの反転操作を行う場合, 操作中に渦構造が壊 れてしまうことも考えられる。このため安定して渦コアの 操作を行うためには, 残留磁化状態で渦構造が安定して現 れるディスクよりも大きなディスクが必要になることが予 想される. 文献 12 では静的に安定な磁化状態としてラン
ダムな磁化構造を初期值として与え, 緩和してから得られ た状態を安定な磁化構造としている。しかし，この方法か ら得られる構造はエネルギー極小の一つであるが，エネル ギーが最小の構造ではない可能性があった。また，静的な 評価しか行っておらず，渦コアが反転するような動的な条 件での安定性については議論されていなかった。

本論文では残留磁化状態の渦構造の安定性は, 出現する 可能性がある磁化構造のエネルギーを計算し，それらを比 較することで, そのディスクに現れる磁化構造の中で最も エネルギーが低い状態での安定性を計算した。また，動的 な条件での安定性については，実際に $\mathrm{AC}$ 電流による渦コ アの反転シミュレーションを行うことで渦コア反転時に見 られる複雑な磁化構造の動的変化を考慮し, 磁化反転時に 渦構造が崩れずに安定して反転を行うことができるディス クサイズの条件を調べた。

結果として, 残留磁化状態で渦構造が安定して出現する のに必要なディスクサイズよりも，渦構造を崩さずに反転 するには 20 80 nm 程度ディスクの直径を大きくする必要 があることがわかった。また，磁化反転シミュレーション で得られた渦コアの反転エネルギーから同様に条件を調心゙ たところ, 両者の結果が一致することが確認でき, 磁化反 転シミュレーションで得られた結果が妥当であることを示 した.

\section{2. シミュレーション}

計算ではディスクサイズを直径 20 200 nm，膜厚 5 40 $\mathrm{nm}$ で変化させて，その構造の安定性を調べた ${ }^{6)}$. 計算対 象のディスクは $4 \mathrm{~nm} \times 4 \mathrm{~nm} \times$ (膜厚) のセルを用いて離散 化した。各セル内の原子磁気モーメントの運動は 
Landau-Lifshitz-Gilbert 方程式にスピントルク項を導入 した式(1)に従うものとして計算した ${ }^{6)}{ }^{7)}$.

$$
\begin{aligned}
& \dot{\mathbf{m}}=-|\gamma|(\mathbf{m} \times \mathbf{H})+\alpha(\mathbf{m} \times \dot{\mathbf{m}})-\mathbf{u} \frac{\partial \mathbf{m}}{\partial x}, u=\frac{g \mu_{B} J P}{2 e M_{s}} \\
& \mathbf{H}=-\frac{\delta \varepsilon}{\delta \mathbf{M}}, \\
& \varepsilon=A(\nabla \mathbf{m})^{2}-\frac{1}{2} \mathbf{H}^{D} \cdot \mathbf{M}
\end{aligned}
$$

ここで， $\mathbf{m}, \mathbf{H}, \alpha, \gamma$ はそれぞれ原子磁気モーメントの 向き, 原子磁気モーメントに加わる実効磁界, 損失定数, 磁気回転比を表わし, $g, \mu \mathrm{B}, J, P, e, M_{\mathrm{s}}$ は gyromagnetic splitting factor, ボーア磁子, スピン電流密度, 分極率, 電荷, 飽和磁化を表す. $\mathrm{u}$ は電流速度と呼ばれ, そのべク トルは電子の移動方向を表す ${ }^{14)}$ 。ここで, 電流密度はディ スク内で一様であると仮定し，ディスク面を $\mathrm{x}-\mathrm{y}$ 平面，デ イスクに対して垂直な方向(コアが向く方向)を $\mathrm{z}$ 方向とし て計算を行った。電子の移動方向は $\mathrm{x}$ 方向として計算した また， $\mathbf{M} ， \mathbf{H}^{\mathrm{D}}$ はそれぞれ磁気モーメント，静磁界を表わ す. 材料定数は Permalloy の值である $M_{\mathrm{s}}=800 \mathrm{emu} / \mathrm{cm}^{3}$ $A=1.0 \times 10^{-6} \mathrm{erg} / \mathrm{cm}, \quad K_{\mathrm{u}}=0, \quad a=0.01, \quad P=0.7^{7)}$ を用 いた. ディスクの磁気エネルギーは, 式(3)のエネルギー 密度から求めた。

計算では，渦コア反転時の安定性を調べる前に，まず磁 気エネルギーから残留磁化状態における渦構造の安定性を 調べた。この結果は, 後のエネルギーによる安定性の評価 で用いた。

渦コア反転時の渦構造の安定性は, AC スピン電流によ る渦コア反転シミュレーションから求めた。この時, 構造 が渦コア反転後も安定して存在する場合と, 渦構造が崩れ 他の磁化構造へ変化する場合のディスクサイズの条件を調 ベた. 次に, シミュレーションから求めた渦コアの反転エ ネルギーと磁化構造のエネルギーから, 渦構造が崩れずに 反転するディスクサイズの条件を調ベ, 磁化反転シミュレ ーションで得られた結果の妥当性を調べた。

\section{3. 残留磁化状態における安定性}

ここでは, 磁気ディスクに現れる磁化構造のエネルギー から残留磁化状態で安定して現れる磁化構造を求め, 渦コ ア構造が安定して存在するディスクサイズの条件を調べ た.

残留磁化状態における渦コアの安定性についてはすでに 実験とシミュレーションの両方から報告されている 12), 13) しかし, 文献 13 では本論文で用いた Permalloy とは異な る Supermalloy を用いた研究であり，また，文献 12 では 静的に安定な磁化状態としてランダムな磁化構造を初期值 として与え, 緩和してから得られた状態を安定な磁化構造 としている.しかし，この方法から得られる構造はエネル ギー極小の一つであるが，エネルギーが最小の構造ではな
い可能性があった．本論文では，ディスクサイズごとに出 現する可能性がある磁化構造のエネルギーをそれぞれ計算 し, 得られたエネルギーを比較することで, そのディスク で出現する磁化構造の中で最もエネルギーが低い状態で残 留磁化状態の安定性について議論した.

本論文で用いたディスクサイズでは渦構造または単磁区 構造が出現するため ${ }^{12)}$, 各ディスクサイズで渦構造のエネ ルギー $\left(E_{\mathrm{V}}\right)$ と，単磁区構造のエネルギー $\left(E_{\mathrm{SD}}\right)$ を計算し， 両者のエネルギー差 $\left(E_{\mathrm{SD}}-E_{\mathrm{V}}\right)$ より安定して存在する構造 を調べた。ここで，単磁区構造のエネルギーは，十分に大 きな磁界を 1 方向に適用し, 磁化が 1 方向を向いた状態か ら計算をはじめた。 その後, 磁界を切り磁化構造が緩和し た状態のエネルギーを計算した。渦構造のエネルギーにつ いては，単磁区構造のエネルギー計算と同様に磁界を 1 方 向に適用し，磁化が 1 方向を向いた状態から計算をはじめ た。しかし，単磁区構造が安定なディスクサイズでは渦構 造が出にくいため，ディスクに対して垂直な方向に磁界を 適用することで渦構造が出現するようにし，渦構造が出現 した後は磁界を切り, 磁化構造が緩和した時のエネルギー を計算した. Fig. 1 にディスクの直径と膜厚による，両者 の構造のエネルギー差の変化を示す，図中の差し込み図の 矢印は磁化構造を表わす.

ここで渦構造のエネルギーと単磁区構造のエネルギーが 等しくなる線 $\left(E_{\mathrm{SD}}-E_{\mathrm{V}}=0 \mathrm{erg}\right)$ が，残留磁化状態における 渦構造の安定限界の条件となる。また，エネルギー差がプ ラスとなる領域 $\left(E_{\mathrm{SD}}-E_{\mathrm{V}}>0 \mathrm{erg}\right)$ では単磁区構造のエネル ギーが大きいため, 㵝構造が出現しやすく, 反対にマイナ スとなる領域 $\left(E_{\mathrm{SD}}-E_{\mathrm{V}}<0 \mathrm{erg}\right)$ では単磁区構造が出現しや すい.

ここで得られた安定限界の条件は文献 12 で示されてい る結果よりも直径が小さい結果となった。これは文献 12

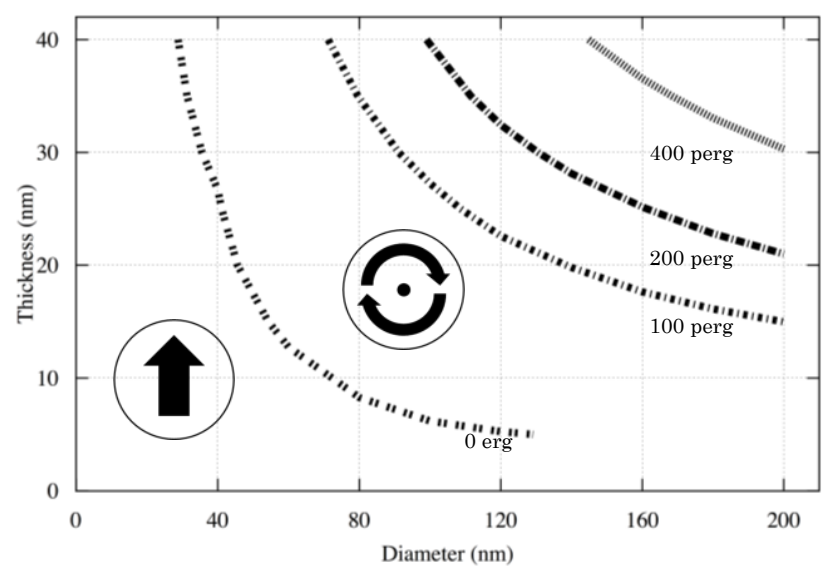

Fig. 1 Change in energy difference between single-domain structure and vortex structure by using disk dimension $\left(E_{\mathrm{SD}}-E_{\mathrm{V}}\right)$. The arrow of the inset figures indicates the magnetization structure of the disk. The single-domain state appears in the left area of the $0 \mathrm{erg}$ line. The vortex state appears in the opposite area. 
ではエネルギー極小状態が得られたためと考えられる。

ここで，円形ディスクを立方体セルで離散化しているた め, セルサイズが得られた結果に影響を与えている可能性 がある、そこで，セルサイズによる影響を調べるために 2 $\mathrm{nm} \times 2 \mathrm{~nm} \times($ 膜厚)セルを用いて同様の計算を行った．直径 が小さいディスクでは元の円形ディスクと離散化したディ スクの体積の差の割合が大きくなる. そこで, セルサイズ の影響が大きいと考えられ，各構造の境界に近い $D=40$ $\mathrm{nm}, h=40 \mathrm{~nm}$ を用いた. 結果として, セルサイズによる エネルギー差は 2 perg程度であった. また, 膜厚が厚いと ころでは膜厚方向にも構造が現れることが考えられるため, $h=30,40 \mathrm{~nm}$ のディスクを直径を変化させて $4 \mathrm{~nm} \times 4$ $\mathrm{nm} \times 5 \mathrm{~nm}$ のセルで離散化した 3 次元モデルを用いて計算 した. 3 次元モデルでは直径, 膜厚がそれぞれ約 $D=80$ $\mathrm{nm}$, 約 $h=30 \mathrm{~nm}$ 以上になると 2 次元モデルで得られた エネルギーと $10 \%$ 以上の差が現れ始めた. このとき, 磁気 ディスク内では膜厚方向にねじれた磁化構造が出現した.

しかし, 安定性の境界となるディスクサイズ付近ではエネ ルギーの差が 6 perg 程度であった。したがって， $h=40$ $\mathrm{nm}$ の場合, 直径が $40 \mathrm{~nm}$ 変化した時にエネルギーが約 100 perg 変化しているため, 得られた安定性限界への影響 は最大で直径 $3 \mathrm{~nm}$ 程度であると考えられる. 以上のこと から計算セル・計算モデルによる計算結果への影響は小さ いと考えられる.

\section{4. 渦コアの反転を伴う場合の安定性}

3 章では, ディスクの磁気エネルギーより, 磁気渦構造 が安定して現れるディスクサイズの条件を求めた。しかし， 磁界またはスピン電流による渦コアの操作を伴う場合, 残 留磁化状態で渦構造が安定して現れるディスクでもこの操 作によって渦構造が崩れてしまうことが考えられる. そこ で本章では, $\mathrm{AC}$ スピン電流を適用し, 渦構造が崩れずに 渦コアが反転するディスクのサイズの限界を調べた. ディ スクサイズの限界を調ベる手法としては, 4.1 章で $\mathrm{AC}$ 電 流による渦コア運動シミュレーションによる手法から渦構 造の安定性を評価し，4.2 章では磁気エネルギーから 4.1 章で得られた結果の妥当性について評価した.

\section{1 渦コア反転シミュレーション}

各ディスクサイズで，AC スピン電流による渦コアの反 転シミュレーションを行い, 渦コア操作を伴う場合の渦構 造の安定性を調べた。㵝コアを効率よく反転させるにはそ の磁気ディスク固有の共振周波数で渦コアを共振回転運動 させる必要がある. そこで, 電流の周波数は各ディスクの 共振周波数に合わせてシミュレーションを行った， AC ス ピン電流を適用した場合, ”渦構造を保ったまま渦コアが定 常回転運動”, “渦コアが反転”, ”渦構造が崩れ他の磁化構造 に変化”の 3 つの磁化構造の変化がみられる. ディスクサイ ズによらず十分に電流密度が低い場合では渦構造を保った
まま渦コアが定常回転運動することが確認できる。一方， 電流密度が高い場合ではディスクサイズによって渦コアが 反転するか渦構造が崩れて他の磁化構造に変化するかは異 なる，そのため，各ディスクで電流密度を変化させ，電流 密度は渦コアが反転するか, 渦構造が崩れ他の磁化構造に 変化するまで上昇させた．Fig. 2 に渦構造が崩れずに渦コ アが反転する限界のディスクサイズを示す.

比較対象として，3 章で得られた残留磁化状態において 渦構造が現れるディスクサイズの限界も破線で示した。渦 構造が崩れずに渦コアが反転する場合，ある一定の回転半 径まで渦コアが移動すると渦-反渦対が現れ，対消滅するこ とで元の磁化方向とは反対の向きの渦コアが残る ${ }^{7)}$. 一方 で, 単磁区構造化する場合では渦-反渦対が出現する前に 渦コアがディスクから脱出してしまうため反転が起こらな い. このとき, 渦コアの回転半径はディスクのエッジまで 増加し, そのままディスクから脱出してしまうことがわか った。 また, 単磁区構造化するために磁化構造にスピント ルクがほとんどかからなくなる，そのため，電流を掛け続 けた場合でも磁化構造の変化がほとんど起こらずエネルギ 一の変化がほとんどなくなる，したがって，渦構造が安定 なディスクサイズであるにも関わらず単磁区構造から渦構 造へ変化するために必要なエネルギーが得られず, 一度単 磁区構造化した場合, 電流を掛け続けても渦構造に戻るこ とは見られなかった。

本章で示した結果は，反転する最小の電流密度での結果 であるが, 用いた電流密度以上の電流を適用しても, 渦コ アがディスクのエッジに達する前に渦コアが反転するため, 本章で得られたディスクサイズの限界は変化しなかった。

また, 単磁区構造化後に電流を切り, 渦構造へ磁化構造が 変化するかについて調べたところ, 残留磁化状態で渦構造 が現れるディスクサイズでも渦構造には戻らないことがわ かった。

これらの結果から残留磁化状態において渦構造が出現す

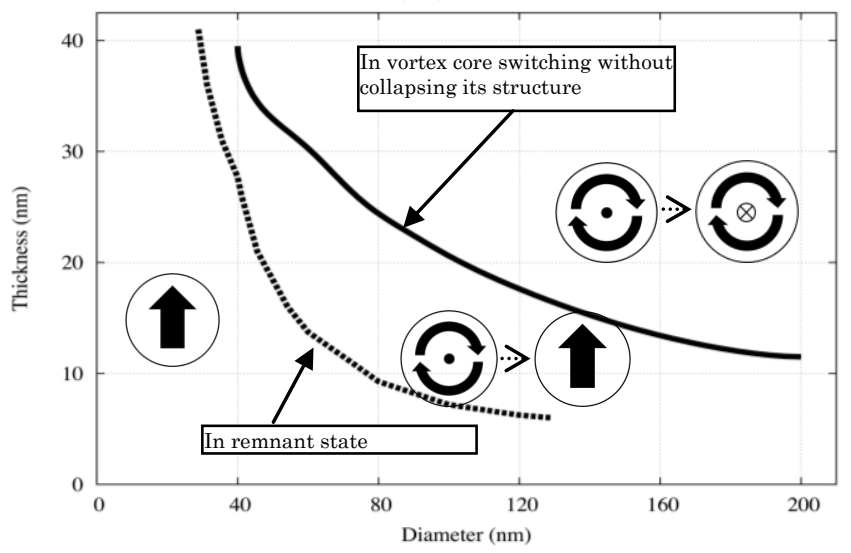

Fig. 2 Limits of stable dimension in the remanent state and in vortex core switching without collapsing its structure. In the right side of the solid line, the vortex core switches. In the opposite side, the vortex structure collapses and changes to the single-domain structure. 
るディスクサイズよりも渦コアが安定して反転するには膜 厚が厚い場合にはディスクの直径を約 $20 \mathrm{~nm}$ 程度, 膜厚が 薄い場合には約 $80 \mathrm{~nm}$ 程度増加させる必要があることがわ かった。

ここで, 3 章で行った検証と同様に計算セル・計算モデ ルによる影響を調べるために、 $2 \mathrm{~nm} \times 2 \mathrm{~nm} \times$ (膜厚)と 4 $\mathrm{nm} \times 4 \mathrm{~nm} \times 5 \mathrm{~nm}$ のセルで離散化したモデルについて計算 を行った。計算セルのサイズはディスクの直径が小さい場 合に影響が現れやすく, 計算モデルは膜厚が厚い場合に影 響を受けやすいため, ここでは $h=40 \mathrm{~nm}$ の場合について 計算を行った. $2 \mathrm{~nm} \times 2 \mathrm{~nm} \times$ (膜厚)のセルを用いた場合, コ アが安定して反転する境界は直径が $42 \mathrm{~nm}$ から $46 \mathrm{~nm}$ の 間と求められた. また, $4 \mathrm{~nm} \times 4 \mathrm{~nm} \times 5 \mathrm{~nm}$ のセルを用いた 場合では直径が $36 \mathrm{~nm}$ から $40 \mathrm{~nm}$ の間と求められた。し たがって, $4 \mathrm{~nm} \times 4 \mathrm{~nm} \times$ (膜厚)のセルを用いて計算した結果 との差は数 $\mathrm{nm}$ であり, 計算セル・計算モデルによる計算 結果への影響は小さいと考えられる。

\section{2 磁気エネルギー}

次にディスクの磁気エネルギーから渦コアが渦構造を 崩さずに反転するディスクサイズの限界を調べた.

まず渦コア反転時や単磁区化のためのエネルギーバリ アを調べるために, AC 電流による渦コア操作シミュレー ションを行い, 渦コアが反転する場合と単磁区構造化する 場合のエネルギーの時間変化を調べた．Fig. 3 に渦コアが 反転する場合 $(D=120 \mathrm{~nm}, h=20 \mathrm{~nm}$ のディスク $)$,

Fig. 4 に磁気渦が崩れ単磁区構造化する場合 $(D=60 \mathrm{~nm}$, $h=20 \mathrm{~nm}$ のディスク)のエネルギーの時間変化を示す.

両方の場合, 電流によって渦コアが回転運動し回転半 径が次第に増加するため, 磁気エネルギーが増加する.こ こで, 各ディスクの単磁区構造のエネルギーと各構造のエ ネルギーの時間変化を比較すると, 渦コアが反転する場合 (Fig. 3)では渦コアのエネルギーは最大となる渦コア反転 時でも単磁区構造のエネルギーより低い。したがって,

Fig. 3 ではコアは一度だけ反転し, 渦構造を保ったまま定

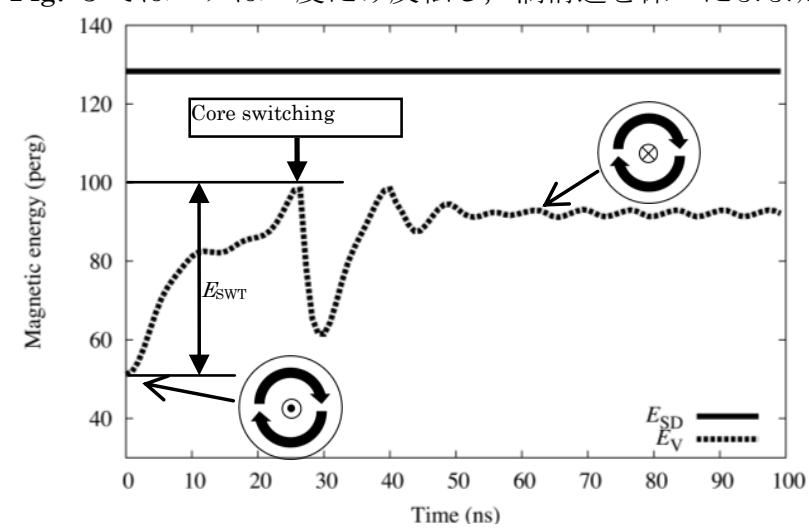

Fig. 3 Change in magnetic energy over time with disks of $D=120 \mathrm{~nm}$ and $h=20 \mathrm{~nm}$. The solid line shows the energy of single-domain state, and the dashed line shows the energy of the vortex state induced by current with $j=4.5 \times 10^{11} \mathrm{~A} / \mathrm{m}^{2}, f=1.17 \mathrm{GHz}$.

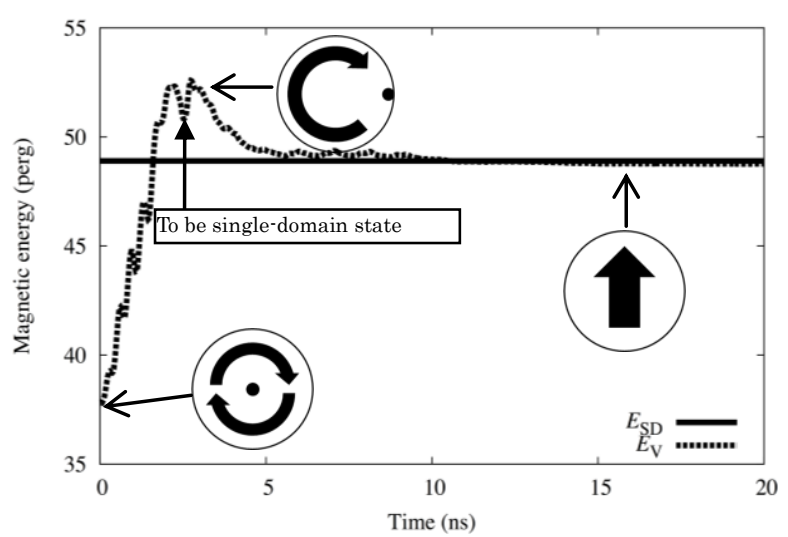

Fig. 4 Change in magnetic energy over time with disks of $D=60 \mathrm{~nm}$ and $h=20 \mathrm{~nm}$. Solid line indicates energy of single-domain state, and dashed line indicates energy of vortex state induced by current with $j=9.6 \times 10^{11} \mathrm{~A} / \mathrm{m}^{2}$ and $f=1.38 \mathrm{GHz}$. When vortex state changes to single-domain, vortex core moves to the edge of disk

常回転運動している. AC 電流による渦コアの反転では電 流を流し続けることで何度も反転すると考えられるが，

Fig. 3 の条件では $1 \mu \mathrm{s}$ まで電流を流し続けても次の反転が 見られなかった，そこで，電流密度を渦コアが反転せず定 常回転運動する $j=4.47 \times 10^{11} \mathrm{~A} / \mathrm{m}^{2}$ まで下げて同様の計算 を行ったところ渦コアが定常回転運動する前に一時的に定 常回転運動時よりもエネルギーが高くなることが確認され た. したがって，Fig. 3 で見られる反転はこの一時的なエ ネルギーの上昇時に起こったものと考えられる。この反転 は一般的な $\mathrm{AC}$ 電流を用いた連続反転とは異なり, 突然電 流を入れたことによる反転であるため, ゆっくりと電流を 入れた場合には電流密度や電流の周波数などの反転条件は 変わることが考えられる。しかし，ディスクサイズが同じ であればゆっくりと電流を入れた場合でも最終的に渦コア が反転するか単磁区構造化するかは渦構造の安定性によっ て決まるため同じ結果が得られると考えられる。したがっ て，本論文で得られた境界条件への影響はないと考えられ る、本論文では反転電流密度を最小かつ一度でも反転する 場合の電流密度としているため, Fig. 3 で示したような $\mathrm{AC}$ 電流で見られる連続反転でない場合についても”渦コアの 反転”とした。一方で，単磁区構造化する場合(Fig. 4)では 単磁区構造のエネルギーを越えた後に単磁区構造化してい ることがわかる. したがって, 単磁区構造化する場合では, スピントルクによって磁化構造が変化し, これに伴い磁気 エネルギーが増加し, 反転を起こす前に単磁区構造のエネ ルギーを越える場合に単磁区構造化することがわかる.

ここで, 反転エネルギー $\left(E_{\mathrm{SWT}}\right)$ を Fig. 3 における初期の エネルギーと反転時のエネルギーの差とすると, 渦構造の エネルギーと反転エネルギーを足した值 $\left(E_{\mathrm{V}}+E_{\mathrm{SWT}}\right)$ が単磁 区構造のエネルギー $\left(E_{\mathrm{SD}}\right)$ よりも小さい場合に渦コアは反 転し, 反対に大きい場合では単磁区構造化することが予想 される，そこで，各ディスクサイズで反転に必要なエネル 


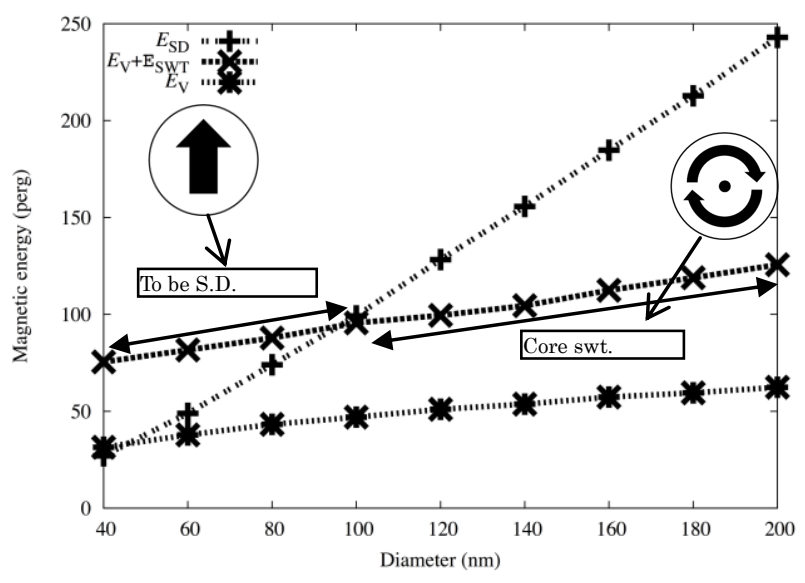

Fig. 5 Change in magnetic energy of each state of disk diameter with disk thickness of $h=20 \mathrm{~nm}$.

ギーを計算し, 反転エネルギーと渦構造, 単磁区構造のエ ネルギーから渦構造が崩れずに反転するディスクサイズを 計算した。 まず，す心゙てのディスクサイズで反転エネルギ 一の計算を行った。単磁区構造化するディスクサイズでは 反転時のエネルギーが得られないため, 反転するディスク サイズの反転エネルギーから補外して計算した. Fig. 5 に ディスクの膜厚を $h=20 \mathrm{~nm}$ で固定し, 直径を変化させた 場合の各エネルギーの変化を示す.

$E_{\mathrm{SD}}, E_{\mathrm{V}}+E_{\mathrm{SWT}}, E_{\mathrm{V}}$ はそれぞれ残留磁化状態の単磁区 構造のエネルギー, 残留磁化状態での渦構造のエネルギー と反転エネルギーを足し合わせたもの, 残留磁化状態の渦 構造のエネルギーを示している. 各エネルギーはディスク の直径に対して線形に変化し, Fig. 4 の結果と同様に $E_{\mathrm{V}}+E_{\mathrm{SWT}}$ が $E_{\mathrm{SD}}$ を越える場合 $\left(E_{\mathrm{V}}+E_{\mathrm{SWT}}>E_{\mathrm{SD}}\right)$ に単磁区構 造化することがわかる.したがって,$E_{\mathrm{V}}+E_{\mathrm{SWT}}=E_{\mathrm{SD}}$ とな る場合が，渦構造が崩れずに渦コアが反転するディスクサ イズの限界であり, 膜厚 $h=20 \mathrm{~nm}$ の場合，渦コアが安定 して反転するには直径が約 $D=100 \mathrm{~nm}$ 以上必要であるこ とがわかる．他の膜厚でも同様にして渦コアが安定して反 転する限界を調べるために， $E_{\mathrm{SD}}-\left(E_{\mathrm{V}}+E_{\mathrm{SWT}}\right)$ を各ディス クサイズで計算した. 結果を Fig. 6 に示す.

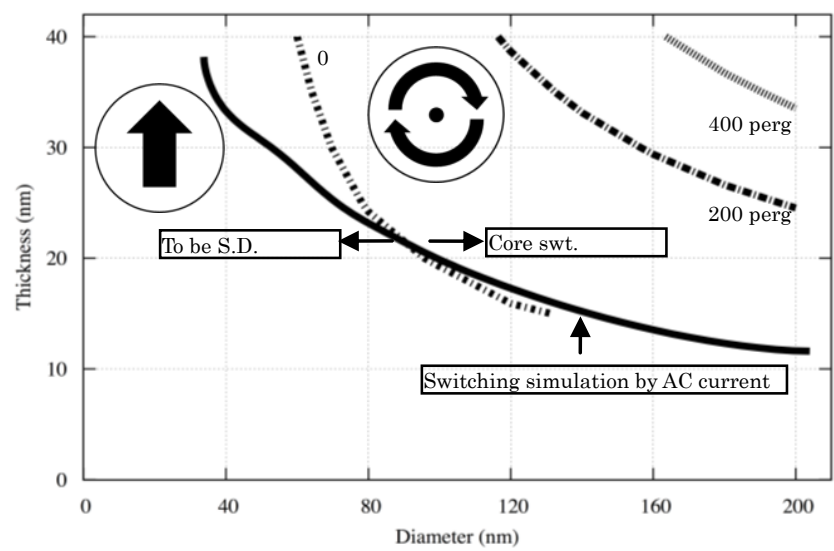

Fig. 6 Change in energy difference by using disk dimension $\left(E_{\mathrm{SD}}-\left(E_{\mathrm{V}}+E_{\mathrm{SWT}}\right)\right)$
図ではまた 4.1 章で得られた渦構造が崩れずに渦コア が反転する境界を実線で示した．膜厚が薄い $h=10 \mathrm{~nm}$ 以 下では直径を大きくしても渦コアが反転せずに単磁区構造 化してしまったため, 膜厚 $h=15 \mathrm{~nm} 40 \mathrm{~nm}$ までの結果 を示した。 得られたエネルギー差がプラスとなる場合, $E_{\mathrm{SD}}$ が十分に大きいため, 渦コア反転時でも渦構造のエネ ルギーは $E_{\mathrm{SD}}$ を越えずに渦コアが反転する，一方で，エネ ルギー差がマイナスとなる場合は，渦コアの回転運動中に $E_{\mathrm{SD}}$ を越えてしまい単磁区構造化する。エネルギーの差が 0 となる場合, 渦コア回転運動中の渦構造のエネルギーの 最大值が $E_{\mathrm{SD}}$ と等しくなる。したがって， $E_{\mathrm{SD}}$ $\left(E_{\mathrm{V}}+E_{\mathrm{SWT}}\right)=0$ となる境界が渦コアの反転を伴う場合の単 磁区構造化と渦コアの反転を分ける境界である.

Fig. 6 の結果は，渦コア反転シミュレーションから得 られた渦構造が崩れずに反転する境界（Fig. 2) とほぼ一 致しており，磁気エネルギーから渦コア反転シミュレーシ ヨンで得られた結果の妥当性が確認された。しかしながら, 膜厚が $h=30 \mathrm{~nm}$ 以上で膜厚が増加するにつれて反転シミ ユレーションから得られた結果とのずれが大きくなってき ている，これは，反転エネルギーが余分に大きく得られた ためであると考えられる，特に，膜厚が厚く，直径が小さ いところでは反転時の磁化構造が変化する割合が大きいた め, 純粋な反転に必要なエネルギー以外のエネルギーが加 わったと推測される.

ここで, 4 章で得られた結果は文献 12 で示されている結 果とほぼ一致した。一度渦構造が単磁区構造化した場合に, 電流を切った後でも渦構造へ戻らないことからもわかるよ うに単磁区構造化後はエネルギー極小状態である．したが って, 文献 12 で得られているエネルギー極小状態と 4 章 で得られた境界条件の結果が一致することがわかった。

最後に， 3 章， 4.1 章で行った検証と同様に計算セル・ 計算モデルによる影響を調べるために， $2 \mathrm{~nm} \times 2 \mathrm{~nm} \times($ 膜 厚)と $4 \mathrm{~nm} \times 4 \mathrm{~nm} \times 5 \mathrm{~nm}$ のセルで離散化したモデルについ て計算を行った。ここでは、本章で得られた安定性の境界 に近く, 最も膜厚が厚い $D=60 \mathrm{~nm}, h=40 \mathrm{~nm}$ について計 算を行った. $2 \mathrm{~nm} \times 2 \mathrm{~nm} \times($ 膜厚) と $4 \mathrm{~nm} \times 4 \mathrm{~nm} \times($ 膜厚 $)$ で離 散化したモデルの結果を比較すると $7 \mathrm{perg}$ 程度の差がみら れた。また， $2 \mathrm{~nm} \times 2 \mathrm{~nm} \times$ (膜厚)と $4 \mathrm{~nm} \times 4 \mathrm{~nm} \times 5 \mathrm{~nm}$ で離 散化したモデルの結果を比較した場合では 9 perg程度の差 がみられた。 $h=40 \mathrm{~nm}$ の場合，エネルギーは直径が約 60 $\mathrm{nm}$ 変化した時に 200 perg 変化しているため, 安定性境界 への影響は最大で直径 $3 \mathrm{~nm}$ 程度であると考えられる.ま た, 残留磁化状態では直径, 膜厚が $D=80 \mathrm{~nm}, h=30$ $\mathrm{nm}$ 以上で 3 次元モデルを用いた場合に膜厚方向にねじれ た構造が出現することが確認された。そのため，エネルギ 一による評価でねじれた構造が与える影響を確認するため に $h=30 \mathrm{~nm}$ においてコアが安定する境界を調べた．結果 として, 境界は直径 $69 \mathrm{~nm}$ と求められ，2 次元モデルの結 果とほぼ一致することを確認した．以上のことから計算セ 
ル・計算モデルによる計算結果への影響は小さいと考えら れる。

\section{5. まとめ}

本論文では，マイクロマグネティックシミュレーショ ンを用いて, 渦コアの構造が崩れずに磁化反転するディス クサイズの条件を求めた。この条件の評価は, 磁化反転シ ミュレーションを用いて調べ, さらに磁化反転時のエネル ギーから得られた結果の妥当性を調べた。

磁化反転シミュレーションでは，渦構造が崩れて単磁区 構造化する場合, コアの磁化反転は起こらず, 渦コアの回 転半径はディスクのエッジまで増加し, そのまま脱出する ことがわかった。また，磁化反転時のエネルギーからは， スピントルクによって磁化構造が変化し，これに伴い磁気 エネルギーが増加し，反転を起こす前に単磁区構造のエネ ルギーを越える場合に単磁区構造化することがわかった. これらの評価手法で得られた渦構造が崩れずに反転する条 件はほぼ一致し, 磁化反転時のエネルギーから磁化反転シ ミュレーションで得られた結果の妥当性を確認した。ここ で得られた条件から, 残留磁化状態で渦構造が安定して現 れるのに必要なディスクサイズよりも，渦構造を崩さずに 渦コアが反転するには 20 80 nm 程度ディスクの直径を大 きくする必要があることがわかった。

謝辞 本研究の一部は，文部科学省科学研究費補助金特定 領域研究「スピン流の創出と制御」の助成により行われた.

\section{References}

1) J. Raabe, R. Pulwey, R. Scattler, T. Schweinböck, J. Zweck, and D. Weiss: J. Appl. Phys., 88, 4437 (2000).

2) T. Okuno, K. Shigeto, T. Ono, K. Mibu, and T. Shinjo: $J$. Magn. Magn. Mat., 240, 1 (2002).

3) A. Thiaville, J. M. Garcia, R. Dittrich, J. Miltat, and T. Schrefl: Phys. Rev. B, 67, 094410 (2003).
4) S.-B. Choe, Y. Acremann, A. Scholl, A. Bauer, A. Doran, J. Stöhr, and H. A. Padmore: Science, 304, 420 (2004).

5) B. Van Waeyemberge, A. Puzic, H. Stoll, K. W. Chou, T. Tyliszczak, R. Hertel, M. Fahnle, H. Bruckl. K. Rott, G. Reiss. I, Neudecker, D. Weiss, C. H. Back, and G. Schutz Nature, 444, 461 (2006).

6) S. Kasai, Y. Nakatani, K. Kobayashi, H. Kohno, and T. Ono: Phys. Rev. Lett., 97, 107204 (2006).

7) K. Yamada, S. Kasai, Y. Nakatani, K. Kobayashi, H. Kohno, A. Thiaville, and T. Ono: Nature Mat., 6, 270 (2007).

8) R. Hertel, S. Gliga, M. Fähnle, and C. M. Schneider: Phys. Rev. Lett., 98, 117201 (2007).

9) B. Krüger, A. Drews, M. Bolte, U. Merkt, D. Pfannkuche, and G. Meier: Phys. Rev. B, 76, 224426 (2007).

10) S.-K. Kim, K.-S. Lee, Y.-S. Choi, and Y.-S. Yu: IEEE Trans. Magn., 44, 3071 (2008)

11) T. Kamionka, M. Martens, K. W. Chou, M. Curcic, A. Drews, G. Schütz, T. Tyliszczak, H. Stoll, B. V. Waeyenberge, and G. Meier: Phys. Rev. Lett. 105, 137204 (2010).

12) M. Konoto, A. Fukushima, R. Matsumoto, H. Kubota, K. Yakushiji, A. Sawa, S. Yuasa, and K. Ando: Appl. Phys. Express, 3, 063001 (2010).

13) R. P. Cowburn, D. K. Koltsov, A. O. Adeyeye, and M. E. Welland: Phys. Rev. Lett., 83, 1042 (1999).

14) A. Thiaville, Y. Nakatani, J. Miltat, and Y. Suzuki: Europhys. Lett., 69, 990 (2005).

15) K. Y. Guslienko, V. Novosad, Y. Otani, H. Shima, and K. Fukamichi: Phys. Rev. B, 65, 024414 (2001).

16) K. Y. Guslienko, B. A. Ivanov, V. Novosad, Y. Otani, H. Shima, and K. Fukamichi: J. Appl. Phys., 91, 8037 (2002).

17) A. Ivanov, and C. E. Zapel: J. Appl. Phys., 95, 7444 (2004).

18) X. Zhu, Z. Liu, V. Metlushko, P. Grütter, and M. R. Freeman: Phys. Rev. B, 71, 180408 (2005).

19) K. Y. Guslienko, X. F. Han, D. J. Keavney, R. Divan, and S. D. Bader: Phys. Rev. Lett., 96, 07205 (2006).

20) K. Y. Guslienko, K.-S. Lee, and S.-K. Kim: Phys. Rev. Lett., 100, 027203 (2008).

21) M. Weigand, B. Van Waeyenberge, A. Vansteenkiste, M. Curcic, V. Sackmann, H. Stoll, T. Tyliszczak, K. Kaznatcheev, D. Bertwistle, G. Woltersdorf, C. H. Back, and G. Schütz: Phys. Rev. Lett., 102, 077201 (2009).

22) S. Barman, A. Barman, and Y. Otani: IEEE Trans. Magn., 46, $1342(2010)$

23) T.-Y. Chen, and P. A. Crowell: IEEE Trans. Magn., 46 , 1457 (2010)

\section{1年10月28日受理， 2012年03月30日採録}

